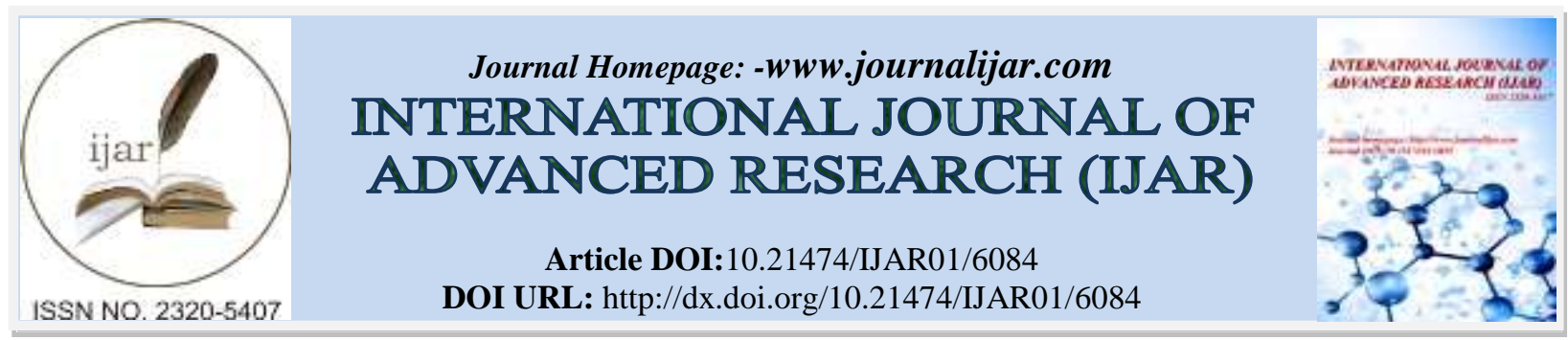

RESEARCH ARTICLE

\title{
RIVER INTER-LINKING (RIL) PROJECT: A QUESTION ON INDIAN FEDERALISM.
}

\section{Dr. Shazia Waheed ${ }^{1}$ and Dr. Pradip Kumar Jha ${ }^{2}$.}

1. Centre for Federal Studies, JamiaHamdard, New Delhi.

2. Academic Counsellor, Indira Gandhi National Open University (IGNOU), New Delhi.

\section{Manuscript Info}

Manuscript History

Received: 17 October 2017

Final Accepted: 19 November 2017

Published: December 2017

Keywords:-

River Inter-Linking, federalism, resource

sharing, judicial activism.

\begin{abstract}
The Supreme Court of India, in 2002 directed the central government to link major Indian rivers within 10 years. In December 2002, the government appointed a task force on interlinking of 37 rivers and the dead line was extended by 2016 . The RIL project not only raises national issue but also give way to international conflict in South Asia over sharing of river waters. The paper examines the impact of the RIL project on the paradigms and working of Indian federalism. It is based on triangulation of theory and qualitative method that applies content analysis of primary and secondary sources to draw conclusion. It finds that in the Indian Constitution water is in the State List while inter-state river is in the Union List and taking up such a mega RIL project without the consent of the concerned states is unacceptable. It considers the directive of the Supreme Court indeed, as an act of judicial activism.
\end{abstract}

Copy Right, IJAR, 2017,. All rights reserved.

\section{Introduction:-}

The Supreme Court of India in its judgement on the $27^{\text {th }}$ of February 2012 has directed the central government to implement the dormant RIL project, in response to the Civil Writ Petitions Nos. 512 \& 668 of 2002, which is assumed to resolve the water scarcity problem throughout the country. In India there are three major river systemsIndus, Himalayan and peninsular. The RIL project is all about transfer of water from the Himalayan River system to the peninsular river system. The proponent of the project in the PIL (Public Interest Litigation) has claimed that 'why cannot a government of free India link its rivers when even a colonial government had linked all the states of India by railways' (Prasad, 2004a:1220). They further forwarded two main justifications for the project: 'the first is that RIL is an answer to the occurrence of floods in some areas of the country and aridity in other areas. The project will provide some relief from floods and supply more water to arid areas. The second is that some river basins have excess water while others have deficiency, and that the project will transfer water from the surplus to the arid region. It must be noted that these are two distinct hypotheses, but they are often mixed up'(Iyer, 2012a). In reality there is no existence of any approved project called "the inter-linking of rivers"; the advocates of the project claim that 'RIL is not a project but a grand concept; but if it is a concept, then question arises how can it be implemented? First it has to be translated into projects and each one of those projects (a total of 30 links, each one a project, and involving in all more than 60 dams, perhaps closer to 80 ) has to be correctly checked, apprised and approved or rejected, as the case may be. After that the question of implementation would arise. It is hypothetically possible that the scrutiny and consent may result in all the projects being cleared, or all the projects declined or some being cleared and some declined. A blanket direction to implement the project as a whole (i e, 30 projects) is clearly inappropriate' (Iyer, 2012b). This direction of the Supreme Court is very much like intruding in the sphere of executive, it assumed that a 
vacant space has been created because of non-action of the executives, and it has to step in and put forward necessary directions for the execution of the plan lingering for years, which is called a "vacuum-occupying theory'(Iyer, 2012c:36). However, this is not the case here, it is already declared that the "delay" of the project "is not the outcome of executive failure or inefficiency, but a planned (though unstated) delay of action on the project. Unluckily the United Progressive Alliance (UPA) government's attitude towards the project was never made unambiguously clear either to the common public or to the Supreme Court. It is the uncertainty that enabled the Supreme Court to issue its directive' (Iyer, 2012d).

\section{Literature review:-}

Over the years considerable amount of literature have come up that either deal with RIL or Indian federalism. The available literature on RIL focuses on hydrological, environmental and resettlement and rehabilitation aspect. In the same way literature on federalism deals with in the context of inter-state relations, power sharing and coalition politics. Attempt is made to compare and contrast concepts of RIL and Indian federalism and their linkages in the context of Supreme Court judgement. The literature on RIL project reveals that it needs objective review and reconsideration of matter as official justification lacks scientific reasoning (e g, Ramaswamy R. Iyer 2002; A Vaidyanathan 2003; T. Prasad 2004; Jayanta Bandyopadhay and Shama Perveen 2004) while India's National River Linking Project (NRLP) examines few contentious issues and concludes that the donor basins may have surplus water to make NRLP technically feasible (e g, UpaliAmarasinghe 2012).

It is evident from above literature that RIL has been recurring concerns of researchers, policy makers and academics. However, the focus of research and studies has been shifting over the years. Though substantive literature have come up during last few years, the nuances of addressing the issue of RIL and Indian federalism in the context of Indian judiciary have not been properly addressed.

\section{Objective:-}

India is a quasi-federal state. In the Indian Constitution water is in the State List while inter-state river is in the Union List. The Supreme Court of India has directed the central government to implement the RIL project. There are broadly four issues like resettlement and rehabilitation of displaced, environmental concern, sharing of costs and benefits among states and international water conflict in the implementation of RIL project. The paper attempts to examine concepts of RIL and Indian federalism and their linkages in the context of Supreme Court judgement.

\section{Research methods:-}

Theoretical triangulation is applied not only to gain the individual strength but also to compensate for particular faults and limitations of any single perspective. The application of triangulation of theory provides the strength of perspectives and additionally avoids the shortcomings of single perspective in detailed understanding of RIL project. The use of triangulation of theory enables to investigate RIL project from a variety of different angles and perspectives, focusing on different research questions and issues, collection of different types of data and interpretation of results from a variety of different positions. The subject matter of research is South Asia in general and India in particular. The universe of research is broad and involves large amount of text. Therefore, qualitative method is applied that follows content analysis of primary and secondary sources to draw conclusion.

\section{RIL in India: a historical sketch:-}

In India the concept of RIL was the brain child of Colonel Arthur Cotton a hydraulic engineer. The basic idea which prompted him to put forward such a proposal was to link 'the Indian subcontinent through a grid of navigation and irrigation canals'(D'Souza, 2003a: 3785), as a major means of communication and inland transportation instead of railways. As his proposal was antithetic to the railways, therefore, he declared it as an 'inferior mode of conveyance' (D'Souza, 2003b:3785). The plan he proposed in 1858, includes 'a peninsula system ... link Karachi in the northwest to Madras in the south via Kanpur, Calcutta and Cuttack, with additional lines to Poona and the west coast' (D’Souza, 2003c: 3785). His proposal received a severe setback because it needed to draw capital investment and the railways project got trump as a major mode of mass transportation in India which was much feasible and less expensive. In the year 1972 the idea of interlinking of rivers was reignited by the then Union Minister of power and irrigation K.L. Rao, he proposed to link the Ganga and the Cauvery rivers through a 2,640 km long canal to transfer the surplus water of Ganga and Brahmaputra to the central and southern India, named as "national water grid". Once again, in 1974 Captain Dastur, an air pilot 'proposed that a 4,200 km long Himalayan canal and 9,300 km long southern canal be linked up at Delhi and Patna'(D'Souza, 2003d: 3785), his proposal was popularised as “Garland Canal". The Central Water Commission and other expert bodies studied the said project and did not find it worthy 
for serious consideration. The Union government established the National Water Development Agency (NWDA) in the year 1982 to 'took up the assignment of developing a proposal for interbasin transfer of water that would be more comprehensive than previous ones. The NWDA proposals for long-distance interbasin transfers have not been openly expressed so far with any technical details. As a matter of fact, the proposal is reportedly still at the stage of an idea, and not yet a project' (Bandyopadhyay and Perveen, 2004a). After conducting many studies and publishing many reports the NWDA had never came up with the idea of river interlinking. Henceforth, the National Commission for Integrated Water Resources Development Plan (NCIWRDP) was set up to scrutinise the two grand projects. The NCIWRDP submitted its report in 1999, with a concluding remark that, K.L. Rao's 'national water grid was very costly and lower cost alternatives were available, on the other hand Captain Dastur's Garland Canal was prima facie impractical' (D'Souza, 2003e). The NCIWRPD finally came up with the report that 'the interlinking proposal attempts to provide large-scale human-induced connectivity for water flows in almost all parts of India, through a total of 31 links on both the Himalayan and peninsular rivers. None of the pre-feasibility or feasibility studies are available in the public domain for an independent professional appraisal of the technical and economic justifications for these links. However, many politicians have described the project as a win-win situation for mitigation of floods and droughts' (Bandyopadhyay and Perveen, 2004b). In the year 2002, the idea of RIL has been suddenly revived in political, legislative and civil domain when, the then President A.P.J. Abdul Kalam in his Independence Day speech said that, 'the plan to integrate the rivers of India (through interlinking) will be a key driver of the growth of the country and it would not only bring about economic prosperity but emotional integration as well' (Bandyopadhyay and Perveen, 2004c: 5315). Following his speech a PIL was filed in the Supreme Court by advocate Ranjit Kumar, and in repose to PIL the learned judges of the Apex Court has directed the central government to implement the RIL project by 2012, and set up a special committee to carry out the implementation. In December 2002, the government has appointed a task force on interlinking of thirty seven (37) rivers and the dead line was extended by 2016.

The RIL is a grand project, which cannot be conducted without a thorough study of the complications like-

- Compensation for resettlement and rehabilitation of the displaced;

- Compensation for environmental damages from the project;

- $\quad$ Sharing the benefits and costs of the project among the states;

- Cooperative management of the project in international river basins(Bandyopadhyay and Perveen, 2004d: 5315).

Apart from the technical complications river interlinking is very much like 'redrawing of the geography of the country' (Iyer, 2002a: 4596). Asthe RIL project is not a single project, but a grand plan combining number of projects, if it is implemented completely the geographical structure will not be the same as it appears now. The construction of large dams changes the course of rivers that will ultimately and extensively alter the geography of country. The grand plan of transfer of water from one river basin to another which are categorised as "surplus" and "deficit" respectively; expected to solve the problem of 'flood' and 'drought' simultaneously; but it is for sure, that this diversion of water will definitely have some consequences whether major or minor. First of all the rational should be examined which is used to declare one basin as surplus and another as deficit. In reality 'the term surplus and deficit are inappropriate in the hydrological/ecological context and must be abandoned. The current in the river is what it is, neither excess nor deficit; we with our demand call it deficit. If it is deficit, it will disappear with better water management' (Iyer, 2012e). However, there is no such acceptable hydrological mechanism presently available for such quantification of water. On paper this project appears quite impressive and simplistic which is going to provide a real paradigm of water management ultimately resolve the issue of flood and drought by transferring the water of flooded region (termed as surplus basin) to the drought region (termed as deficit basin). The proponents of the project have already assumed that the interlinking of the river will provide complete utilisation of the river water; if not used will get waste into the sea, but they have completely neglected that 'though in modern water science the movement of all drops of water flowing in a river has important ecological roles to play yet in small magnitude. Deflection and extractions of water from natural flows are surely needed but their social, economic and ecological downstream impacts need to be part of project appraisal'(Bandyopadhyay, 2012). It is always to be remembered that the interlinking of rivers is not as simple as providing water throughout the country with water pipelines, it involves both macro and micro issues and it is not possible to move on without resolving them. Again, it will be quite foolish to think of such a 'grand visions of long-distance water transfers from one basin to another, when we cannot even persuade neighbouring states within a basin to agree upon a sharing of waters (e g, Ravi-Beas, Cauvery). The NWDA has been studying the possibilities of linking the peninsular rivers (Mahanadi-GodavariKrishna-Pennar-Cauvery), but Orissa does not agree that there is overflow in the Mahanadi, and Andhra Pradesh 
does not agree that there is overflow in the Godavari' (Iyer, 2002b). The states which are to be benefitted from the water transfer will surely extend its support to the project; on the other hand, the states whose water are to be transferred to another basin will undoubtedly oppose it. In such a situation we should realise that 'we have failed in the course of more than half a century to conclude the intra-basin disputes, it will be sheer lunacy if, on top of that, a more controversial issue, that of interbasin water equity, is added to the already complicated picture' (Bandyopadhyay and Perveen, 2004e).

Some of the consequences of RIL are listed here -

i. Unless the link channels are lined, which will be a cost-prohibitive proposition, they will cause heavy seepage which will not only constitute loss of water under transfer but may also create or exacerbate waterlogging conditions in certain areas.

ii. They are likely to cause substantial displacement of people giving rise to problems of resettlement and rehabilitation. Also, as the people to be displaced will be far from being beneficiaries, it will be difficult for them to identify themselves with the positive aspects of water transfer and hence there is bound to be resistance on their part.

iii. As these long link channels may pass through dense forests and habitats of wildlife, their ecological consequences may be serious and substantive.

iv. Import of vast amount of water in arid or semi-arid areas may adversely affect their dry land ecology(Prasad, 2004b: 1223).

Several issues which may arise due to RIL project are discussed below.

(i). Compensation for resettlement and rehabilitation of the displaced:-Compensation for the displaced people is one of the major problems that will arise due to RIL project. The Supreme Court has directed for complete rehabilitation and resettlement arrangement for the development-induced displaced people without actually calculating the cost of resettlement of the displaced people. Therefore, a social activist 'Arundhati Roy calculated the cost of development-induced displacement and found that big dams displaced 33 million people in the last 50 years. India's Supreme Court initiated another development-induced displacement in the form of RIL project but failed to address the issue in a meaningful way' (Ahmed, 2012a). It is quite clear that RIL project would result in displacement of millions of people and the estimated cost of their rehabilitation will be billions of rupees. Here two questions arise, first what would be the cost of rehabilitation? and the second is, who will pay for rehabilitation? Now the problematic questions should be viewed in the federal set up of Indian polity and whether the centre; the states; the beneficiary states; or the state from which the people are displaced would bear the cost of rehabilitation.

(ii). Compensation for environmental damages from the project:-

For the protection of environment, all the developed, developing and underdeveloped countries are making collective efforts with the help of the United Nations (UN). In such an atmosphere each and every project is required to get the environmental clearance for its execution that measures the adverse impact of the project on environment. Large amount of irrevocable environmental damage may put any project out of execution. In an analytical terms it is said that, 'every large dam kills a river, it plays havoc on flora and fauna' (Iyer, 2012f). In such a situation 'big dams, reservoirs and conveyance systems will not only require large investments but also substantial environmental impacts and displacement/rehabilitation problems. All this will need to be analysed at very closely in every case. RIL project is unlikely to survive such scrutiny' (Iyer, 2002c). The environmentalists are against the execution of RIL project because of its unalterable damage to the environment. In case of its implementation, a big question arises what would be the compensation to the environmental degradation? And who will pay for it?

\section{(iii). Sharing the benefits and costs among the states:-}

We are very much aware of the fact that, 'lifting, tunnelling and long circuitous routing around mountains in interbasin transfer certainly involve heavy capital investments and continuing energy costs' (Iyer, 2002d). The exponent of the RIL project claims that, it is going to solve the problems of flood and drought simultaneously; in such a situation it can be assumed that both the surplus and deficit basin states are the beneficiaries. But basins which are categorised as surplus are not ready to accept the claim, in response to the Supreme Court's judgement for the implementation of RIL project, BrijendraYadav, a Member of Legislative Assembly (MLA) from Janta Dal (United) of Bihar, made an appropriate statement that 'the states located in these basins (Ganga and Brahmaputra) were the most undeveloped states of the country. If Bihar is not able to utilise its water, it is construed to be a surplus state. You think of a patient who has lost his appetite and cannot take food. Does it mean that he has surplus food with him?' (Mishra, 2012: 48). 
BrijendraYadav in his statement absolutely denied the presence of any surplus water; therefore, the transfer of their water to the other region would be at their expense. Hence, the region which are getting water are extending their support to the project, on the other hand the basin from which water is transferred are not willing to encourage the implementation of the project; as they are not considering themselves as the beneficiaries, therefore, it is quite obvious that they are not going to share the cost of the project. In such a complicated situation, it is very much required to have an extensive debate and discussion between the Union, the states, consolidation of expert opinion and the stake holders to reach a consensual agreement on the cost and benefit sharing of the RIL project which requires million of rupees for its execution.

The RIL project is not only creating complications in the domestic affairs but also giving way to the international conflicts. Therefore, it is relevant to discuss the pros and cons of RILproject at the international level.

\section{(iv). International water conflict:-}

The RIL project is not confined to inter-basin antagonism only; it also cultivates complex relations with the coriparian countries. The proposed project includes two river systems- The Himalayan rivers and the peninsular rivers. The basins of peninsular rivers are within the geographical boundary of India; and on the other hand the Himalayan riversare trans-national and share their basins with Bangladesh, Nepal and Bhutan. 'Bangladesh has 57 crossboundary rivers. Out of 57, it shares 54 with India and the remaining 3 with Myanmar. There would be adverse impact on Bangladesh's economy, society, environment and even polity due to any change in the flow of any of the 54 rivers shared by Bangladesh and India' (Ahmed, 2012b). It should be noted here that the recent Supreme Court's Judgement on river interlinking project deals with both the Himalaya and peninsular river systems, Bangladesh being a co-riparian country in the Himalayan river system is much more concerned with it, because the judgement involves 'India, Bhutan and Nepal' (Ahmed, 2012c). In effect of which it has stated that:

The north of Bangladesh is already dying out after the Ganges was dammed by India in 1976. Now India is planning to do the same on [many of] the 53 other rivers that enters the country via India. Bangladesh depends completely on water ... We want no kind of war, but international law on sharing water is unsure and we would request the UN to frame a new law. It would be a last resort(Bandyopadhyay and Perveen, 2004f: 5315).

The worries of the Bangladesh's Water Minister can be justified by inspecting the damage of ecosystem of the downstream areas in Bangladesh because of withdrawal of the Ganga water at Farakka. There are many ecological imbalances because of Farakka barrage like, 'many rivers are drying up, flora and fauna in peril and decay of Sundarbans. Farakka has deepened the arsenic contamination of groundwater in Bangladesh. This list of harmful effects of Farakka on Bangladesh can be made longer' (Islam, 2006a). It is not only the cause of conflict at international level but became a significant reason of unrest at national level also; because certain areas in Bihar is getting additionally flooded by it and 'the affected people are now regularly coming out in processions demanding that the Farakka be demolished. Farakka barrage itself has become a perennial problem in respect of engineering and financial costs. In India-Bangladesh bilateral relationship Farakka has been a major source of tension. It is true that there have treaties over Farakka creating the impression that the issue has been resolved. However, most people in Bangladesh continue to consider withdrawal of Ganges water at Farakka as unfair, and in Bangladesh's popular psyche,Farakka continues to be a symbol of India's hubris and maltreatment of her small neighbour' (Islam, 2006b). The construction of storage reservoir and interlinking of the Himalayan riverswill give way to a fresh set of conflict between Bangladesh and India. Her worries lies in the displacement of its own people due to the ecological imbalance bound to be created by unilateral action of the Indian government by implementing RILproject, the displaced people 'could end up as environmental refugees across the border! Apart from Bangladesh, India will also have to consider the international impact of this river linking project on Nepal, Bhutan and Pakistan. As it is, India and Pakistan have seen many points of conflict over the existing river sharing pacts' (Ahmed, 2012d: 53). The complexity of the situation increases when the downstream area belongs to another country, India is already experiencing unresolved intra-basin conflict over the sharing of river water among the states situated within the country. Therefore, it is quite possible that the proposed 'RIL project would end up escalating the already bitter trans-boundary conflict over water sharing and availability from the village to the country levels' (Bandyopadhyay and Perveen, 2004g).

'Article 7 of the UN Convention on the Law of the Non-navigational Uses of International Watercourses directs the watercourses states to prevent significant harm to other watercourse states and in case of significant harm the watercourse state responsible for harm needs to eliminate or mitigate such harm and where appropriate, to discuss 
the question of compensation' (UN Convention on the Law of the Non-navigational Uses of International Watercourses, 1997). The direction of the Supreme Court for the implementation of the RIL project has completely neglected the UN Convention on the Law of the Non-navigational Uses of International Watercourses. Therefore, a conscious effort is required to deal with the issue involving another country. It is required to get the consent and reach a mutual concurrence of the co-riparian country before taking up step on the direction of implementation of RIL project.

The issue of federalism is the most important one in the series of complexities coming in the way of RIL project.

\section{Federalism ignored:-}

The recent direction of the Supreme Court on the RIL project has diverse federal questions like-

- Is it changing the power sharing arrangement between the central and state government?

- Is it an encroachment of the judiciary in the executive domain?

- Is it judicial activism or not?

The expert in the field of hydrological management Ramaswamy R. Iyer has very well said that, 'we have not so far been able to persuade states within a basin to share river waters (e g, the Cauvery dispute); instead of resolving such intra-basin disputes through the better, more economical and more cooperative management of the resources of the basin, should we try to bring water from another and more distant basin?'(Iyer, 2003: 913). Without any doubt it can be clearly stated that the interlinking of rivers will definitely involve interstate issues. In the recent past India has witnessed number of unresolved intra-basin conflicts over the sharing of river water. Therefore it is very well known that 'in order to solve disputes related to shared water resources various mechanisms - constitutional, legal and jurisprudential - have been evolved to guide co-basin conduct to resolve conflict. There are no constitutional or legal provisions and norms to guide the states to be hydraulically interconnected through synthetic link channels interlinking their rivers. In such a situation it will be difficult to resolve the disputes. In this view, RIL project is potentially fraught with the grim prospect of giving rise to irreversible conflicts among states all across the country' (Prasad, 2004c). If we neglect all the technical and social aspects, absence of any well developed constitutional and legal mechanism will not allow the successful implementation of RIL project. The power sharing arrangements between the central and state governments is to be disturbed, as water is primarily a state subject (Entry 17, List II, in the $7^{\text {th }}$ Schedule), moving ahead with the project without getting the consent of the state governments; will shatter their aspirations not only politically but legally as well. This paradigm shift in power sharing arrangement is unacceptable by the state governments as it is totally against the spirit of federalism. India is a "quasi federal" country as maximum concentration of power lies at the centre; the transfer of more power from the state to the central government will put the tag of 'unitary' on it. As per Indian Constitution the central government is provided with a significant role in the interstate rivers, 'but it does not make any reference to inter-basin transfers and includes no enabling provision for central intervention to bring them about. Suppose that there is need of inter-basin transfers in some exceptional cases, they cannot be ordered by the central government or mandated by the Supreme Court; they can only be brought about by consent' (Iyer, 2012g). Moreover, 'though politicians have been talking of the need for shifting control over the water sector from the state to the centre, at least partially, no clear thought has been given on how to alter the present institutional structure to accommodate these modifications amicably' (Bandyopadhyay and Perveen, 2004h: 5315). It must be noted that the RIL project extensively combines importance with complexity. The Supreme Court has made contradictory and unjust statement on the part of the state government by pronouncing that 'the state Governments are expected to view national problems with a greater objectivity, rationality and spirit of service to the nation and... ill-founded objections may result in greater harm, not only to the neighbouring states, but also to the nation at large' (Iyer, 2012h: 35). Upholding the principle of unity does not mean losing the spirit of federalism both should come together rather than contradict each other.

The Constitution of India has adopted both the principle of "separation of power"and "checks and balances" to assure that the three branches of the federation- executive, legislature and judiciary; are able to perform their task with competency and efficiency. Area of their jurisdiction and the tasks to be performed by each are very sharply defined. The separation of power allows them to function independently without any interference; and the checks and balances restrict one's jurisdiction from acquiring excess amount of power and encroachment in the domain of others. The direction of the Supreme Court for the implementation of RIL project is a crystal clear intervention of the judiciary in the executive domain- 'the RIL project decision has been taken away from the government; the government and Planning Commission have been reduced to the position of subordinate offices or implementing agencies of Supreme Court' (Iyer, 2012i). Furthermore, 'the direction of the Supreme Court to implement RIL 
project is a deeply disquieting judgement because it is encroachment into executive domain, inadequate awareness of the extensive debate on the project and strong backing to a project that many consider to be fundamentally flawed and potentially disastrous' (Iyer, 2012j). This judicial intervention has also diluted the accountability of the executive, because in case of any mischievous outcome it can be on safer side by pronouncing that it was only following the Supreme Court's direction. Not only this, the power and authority of the Comptroller and Auditor General's (CAG) work is also restricted by this act of Supreme Court because 'the CAG will be not be able to appraise the soundness of the project decision because that would amount to questioning the Supreme Court. Judicial direction to implement a particular project also exempts the project from judicial review. No civilian or institution can go to court against a project mandated by Supreme Court. One wanders whether the learned judges considered these implications' (Iyer, 2012k). Finally, the extension of the jurisdiction of the judiciary in the executive domain minimises the authoritative sovereignty of the executive; both its power and function will get immensely receded.

It is relevant to examine whether the direction of the Supreme Court for the implementation of the RIL project, in response to the writ petition filed in 2002, is an act of 'judicial activism' or not? It is well known that 'Mandamus' is a writ petition which enables the Supreme Court to exercise its power to direct the public authority to perform their task in case of non performance; which is hindering the fundamental rights of a citizen of India as a whole. Therefore, primarily it is to be examined whether that the present case of RIL project falls under the criteria of writ petition or not.Here 'the Supreme Court seems to have assumed that the linking of rivers was an accepted idea that has been languishing for decades for want of attention and action. If so, a direction to accelerate action may seem a legitimate exercise of judicial activism' (Iyer, 2002e: 4595). The Supreme Court 'in order to secure the objective of human rights, ensure justice and protect environment the judiciary stretches its scope or jurisdiction or concerns. No such justification is available in the case of RIL project' (Iyer, 2002f). Because, the right to drinking water is the part of the right to life, and the Supreme Court has the power to direct the state to ensure that right, but the process through which this right is to be assured does not fall under its domain, and it is by no means clear that there is a direct link between the right to water and the linking of rivers' (Iyer, 2002g: 4595). In the similar context it can be argued that 'the judiciary is concerned with conflicts and their prevention, but here again, it is only entitled to say: 'find ways and means of avoiding conflicts over river waters', and not: 'transfer waters from surplus to deficit rivers for augmenting the flows of the latter and obviating conflicts' (Iyer, 2002h: 4595). Nevertheless, finally it can be extracted that 'the Supreme Court's direction in this case was not at all a defensible instance of judicial activism. One wonders whether it was a judicial act at all' (Iyer, 2002i: 4595).

The direction of the Supreme Court gives rise to questions that go against the spirit and temperament of Indian federalism.

\section{Conclusion:-}

Scarcity of water is a global issue but the most important fact is that neither the unitary nor any federal countries, are taking up any such assignment like RIL project of India to resolve it. It is a complex and complicated issue that requires comprehensive and unconditional professional assessment and analysis for all the stages of its implementation. The impact of such a grand scheme is irreversible; therefore it requires a very delicate approach. It revolves around the complications developing in the area of federalism or simply challenging the principles of Indian federalism. It finds that in the Indian Constitution water is in the State List while inter-state river is in the Union List and taking up such a mega RIL project without the consent of the concerned states is unacceptable. Due to change in power sharing between center and state government and encroachment of judiciary into executive domain it considers the directive of the Supreme Court indeed, as an act of judicial activism.

The research contributes to the extensive debate on RIL project. It finds that the direction of the Supreme Court to implement RIL project is an act of judicial activism. Future work would benefit by including technical and hydrological complexity involved in RIL project. 


\section{References:-}

1. Ahmed Imtiaz, (2012a), "Teesta, Tipaimukh and River Linking Danger to Bangladesh-India Relations", Economic and Political Weekly, Vol.67 No.16.

2. Ahmed Imtiaz, (2012b), "Teesta, Tipaimukh and River Linking Danger to Bangladesh-India Relations", Economic and Political Weekly, Vol.67 No.16.

3. Ahmed Imtiaz, (2012c), "Teesta, Tipaimukh and River Linking Danger to Bangladesh-India Relations", Economic and Political Weekly, Vol.67 No.16.

4. Ahmed Imtiaz, (2012d), "Teesta, Tipaimukh and River Linking Danger to Bangladesh-India Relations", Economic and Political Weekly, Vol.67 No.16.

5. BandyopadhyayJayanta, (2012), "Water Science in India Hydrological Obscurantism", Economic and Political Weekly, Vol.67 No.16.

6. BandyopadhyayJayanta and ShamaPerveen, (2004a), "Interlinking of Rivers in India: Assessing the Justifications", Economic and Political Weekly, Vol. 39 No. 50.

7. BandyopadhyayJayanta and ShamaPerveen, (2004b), "Interlinking of Rivers in India: Assessing the Justifications", Economic and Political Weekly, Vol. 39 No. 50.

8. BandyopadhyayJayanta and ShamaPerveen, (2004c), "Interlinking of Rivers in India: Assessing the Justifications", Economic and Political Weekly, Vol. 39 No. 50.

9. BandyopadhyayJayanta and ShamaPerveen, (2004d), "Interlinking of Rivers in India: Assessing the Justifications", Economic and Political Weekly, Vol. 39 No. 50.

10. BandyopadhyayJayanta and ShamaPerveen, (2004e), "Interlinking of Rivers in India: Assessing the Justifications", Economic and Political Weekly, Vol. 39 No. 50.

11. BandyopadhyayJayanta and ShamaPerveen, (2004f), "Interlinking of Rivers in India: Assessing the Justifications", Economic and Political Weekly, Vol. 39 No. 50.

12. BandyopadhyayJayanta and ShamaPerveen, (2004g), "Interlinking of Rivers in India: Assessing the Justifications", Economic and Political Weekly, Vol. 39 No. 50.

13. BandyopadhyayJayanta and ShamaPerveen, (2004h), "Interlinking of Rivers in India: Assessing the Justifications", Economic and Political Weekly, Vol. 39 No. 50.

14. D’Souza Rohan, (2003a), "Supply-Side Hydrology in India: The Last Gasp", Economic and Political Weekly, Vol.38 No.36.

15. D’Souza Rohan, (2003b), "Supply-Side Hydrology in India: The Last Gasp", Economic and Political Weekly, Vol.38 No.36.

16. D’Souza Rohan, (2003c), "Supply-Side Hydrology in India: The Last Gasp", Economic and Political Weekly, Vol.38 No.36.

17. D’Souza Rohan, (2003d), "Supply-Side Hydrology in India: The Last Gasp", Economic and Political Weekly, Vol.38 No.36.

18. D’Souza Rohan, (2003e), "Supply-Side Hydrology in India: The Last Gasp", Economic and Political Weekly, Vol.38 No.36.

19. Islam Nazrul, (2006a), "IRLP or the Ecological Approach to Rivers?",Economic and Political Weekly, Vol.41 No.17.

20. Islam Nazrul, (2006b), "IRLP or the Ecological Approach to Rivers?",Economic and Political Weekly, Vol.41 No.17.

21. IyerRamaswamy R., (2012a), "River Linking Project A Disquieting Judgement", Economic and Political Weekly, Vol.67 No.14.

22. IyerRamaswamy R., (2012b), "River Linking Project A Disquieting Judgement", Economic and Political Weekly, Vol.67 No.14.

23. IyerRamaswamy R., (2012c), "River Linking Project A Disquieting Judgement", Economic and Political Weekly, Vol.67 No.14.

24. IyerRamaswamy R., (2012d), "River Linking Project A Disquieting Judgement", Economic and Political Weekly, Vol.67 No.14.

25. IyerRamaswamy R., (2012e), "River Linking Project A Disquieting Judgement", Economic and Political Weekly, Vol.67 No.14.

26. IyerRamaswamy R., (2012f), "River Linking Project A Disquieting Judgement", Economic and Political Weekly, Vol.67 No.14.

27. IyerRamaswamy R., (2012g), "River Linking Project A Disquieting Judgement", Economic and Political Weekly, Vol.67 No.14. 
28. IyerRamaswamy R., (2012h), "River Linking Project A Disquieting Judgement", Economic and Political Weekly, Vol.67 No.14.

29. IyerRamaswamy R., (2012i), "River Linking Project A Disquieting Judgement", Economic and Political Weekly, Vol.67 No.14.

30. IyerRamaswamy R., (2012j), "River Linking Project A Disquieting Judgement", Economic and Political Weekly, Vol.67 No.14.

31. IyerRamaswamy R., (2012k), "River Linking Project A Disquieting Judgement", Economic and Political Weekly, Vol.67 No.14.

32. IyerRamaswamy R., (2003), "Linking of Rivers", Economic and Political Weekly, Vol.38 No.9.

33. IyerRamaswamy R., (2002a), “Linking of Rivers: Judicial Activism or Error?”,Economic and Political Weekly, Vol.37 No.46.

34. IyerRamaswamy R., (2002b), “Linking of Rivers: Judicial Activism or Error?”,Economic and Political Weekly, Vol.37 No.46.

35. IyerRamaswamy R., (2002c), “Linking of Rivers: Judicial Activism or Error?”,Economic and Political Weekly, Vol.37 No.46.

36. IyerRamaswamy R., (2002d), “Linking of Rivers: Judicial Activism or Error?”,Economic and Political Weekly, Vol.37 No.46.

37. IyerRamaswamy R., (2002e), “Linking of Rivers: Judicial Activism or Error?”,Economic and Political Weekly, Vol.37 No.46.

38. IyerRamaswamy R., (2002f), “Linking of Rivers: Judicial Activism or Error?”,Economic and Political Weekly, Vol.37 No.46.

39. IyerRamaswamy R., (2002g), “Linking of Rivers: Judicial Activism or Error?”,Economic and Political Weekly, Vol.37 No.46.

40. IyerRamaswamy R., (2002h), “Linking of Rivers: Judicial Activism or Error?”,Economic and Political Weekly, Vol.37 No.46.

41. IyerRamaswamy R., (2002i), “Linking of Rivers: Judicial Activism or Error?”,Economic and Political Weekly, Vol.37 No.46.

42. Mishra Dinesh Kumar, (2012), "Resuscitating a Failed Idea Notes from Bihar", Economic and Political Weekly, Vol.67 No.16.

43. Prasad T., (2004a), "Interlinking of Rivers for Inter-Basin Transfer”, Economic and Political Weekly, Vol.39 No.12.

44. Prasad T., (2004b), “Interlinking of Rivers for Inter-Basin Transfer”, Economic and Political Weekly, Vol.39 No.12.

45. Prasad T., (2004c), "Interlinking of Rivers for Inter-Basin Transfer", Economic and Political Weekly, Vol.39 No. 12.

46. UN Convention on the Law of the Non-navigational Uses of International Watercourses, (1997), General Assembly resolution 51/229, annex, Official Records of the General Assembly, Fifty-first Session, Supplement No. 49 (A/51/49). 